\title{
Two Distinct Subpopulations of Nestin-Positive Cells in Adult Mouse Dentate Gyrus
}

\author{
Satoshi Fukuda, ${ }^{1}$ Fusao Kato, ${ }^{2}$ Yusuke Tozuka, ${ }^{1}$ Masahiro Yamaguchi, ${ }^{3}$ Yusei Miyamoto, ${ }^{1}$ and Tatsuhiro Hisatsune ${ }^{1}$ \\ ${ }^{1}$ Department of Integrated Biosciences, University of Tokyo, Kashiwa 277-8562, Japan, ${ }^{2}$ Laboratory of Neurophysiology, Department of Neuroscience, Jikei \\ University School of Medicine, Minato-ku, Tokyo 105-8461, Japan, and ${ }^{3}$ Department of Physiology, University of Tokyo, Bunkyo-ku, Tokyo 113-0033, \\ Japan
}

Neurogenesis in the dentate gyrus of the adult mammalian hippocampus has been proven in a series of studies, but the differentiation process toward newborn neurons is still unclear. In addition to the immunohistochemical study, electrophysiological membrane recordings of precursor cells could provide an alternative view to address this differentiation process. In this study, we performed green fluorescent protein (GFP)-guided selective recordings of nestin-positive progenitor cells in adult dentate gyrus by means of nestinpromoter GFP transgenic mice, because nestin is a typical marker for precursor cells in the adult dentate gyrus. The patch-clamp recordings clearly demonstrated the presence of two distinct subpopulations (type I and type II) of nestin-positive cells. Type I cells had a lower input resistance value of $77.1 \mathrm{M} \Omega$ (geometric mean), and their radial processes were stained with anti-glial fibrillary acidic protein antibody. On the other hand, type II nestin-positive cells had a higher input resistance value of $2110 \mathrm{M} \Omega$ and expressed voltagedependent sodium current. In most cases, type II cells were stained with anti-polysialylated neural cell adhesion molecule. Taken together with a bromodeoxyuridine pulse-chase analysis, our results may reflect a rapid and dynamic cell conversion of nestin-positive progenitor, from type I to type II, at an early stage of adult neurogenesis in the dentate gyrus.

Key words: nestin; dentate gyrus; input resistance; adult neurogenesis; neuronal precursor cells; fluorescence microscopy

\section{Introduction}

Accumulated evidence strongly supports the fact that neurogenesis occurs in the dentate gyrus (DG) of the adult mammalian hippocampus (Altman and Das, 1965, 1967; Kaplan and Hinds, 1977; Kaplan and Bell, 1984; Eriksson et al., 1998; Gould et al., 1998). New neurons in the adult DG become granule neurons and make functional synaptic connections with other neurons in vivo (van Praag et al., 2002). Until now, however, the origin of these new neurons has not been identified.

In particular, there has been no report to date describing the functional characteristics, such as the electrophysiological properties, of early stage neuronal precursor cells in the adult DG. In the developing neocortex, neuroepithelial precursor-radial glia cells (Miyata et al., 2001; Noctor et al., 2001, 2002; Tamamaki et al., 2001) generate neurons at the ventricular zone. During the course of this neuronal differentiation, newborn neurons dra-

\footnotetext{
Received Jan. 21, 2003; revised Aug. 21, 2003; accepted Aug. 22, 2003.

This work was supported by a Grant-in-Aid for Scientific Research from the Ministry of Education, Science, Sports and Culture of Japan (T.H.). T.H. is a recipient of grants from The Asahi Glass Foundation. Part of this study was supported by the Bioventure Project of the Ministry of Education, Culture, Sports, Science and Technology, Japan, to the Jikei University School of Medicine (F.K.). We thank Dr. Ron McKay for informative discussion and the gift of anti-nestin antibody, Dr. Tatsunori Seki for useful advice and the gift of anti-PSA-NCAM antibody, Dr. Christian Steinhäuser for critical reading of this manuscript, and Drs. Oliver Brüstle and Shigeo Okabe for informative comments on this study.

Correspondence should be addressed to Dr. Tatsuhiro Hisatsune, Department of Integrated Biosciences, The University of Tokyo, Bioscience Building 402, 5-1-5 Kashiwanoha, Kashiwa Chiba 277-8562, Japan. E-mail: hisatsune@k.u-tokyo.ac.jp.

Copyright $\odot 2003$ Society for Neuroscience $\quad$ 0270-6474/03/239357-10\$15.00/0
}

matically elevate their input resistance (IR) to as much as ninefold higher than that of the precursor cells and begin to display the presence of voltage-dependent currents (LoTurco et al., 1991; Noctor et al., 2001). A similar scenario is suggested in DG by the presence of residual radial glia cells (Eckenhoff and Rakic, 1984).

In this study, we have thus set out to directly assess membrane properties of neural precursor cells, especially at their early stage of differentiation. For this purpose, neural precursor cells in living brain slices must first be identified. We used nestin promoter-green fluorescent protein (GFP) transgenic mice (Yamaguchi et al., 2000) in which nestin second intron enhancers drive enhanced GFP. Nestin is a class IV intermediate filament protein (Hockfield and McKay, 1985; Frederiksen and McKay, 1988; Lendahl et al., 1990) and a marker for precursor cells in the adult DG (Palmer et al., 2000; Blümcke et al., 2001; Nacher et al., 2001a). The nestin gene contains an enhancer in its second intron that directs expression specific to the CNS precursor cells (Zimmerman et al., 1994). We applied the technique of GFP-targeted selective recording (Auerbach et al., 2000) and directly analyzed the electrophysiological membrane properties of GFP-expressing precursor cells in living hippocampal slices. On the basis of analysis of the electrophysiological membrane properties in combination with morphological and immunohistochemical evaluation, we show here that the neural precursor cells expressing nestin in the DG can be classified into two distinct subpopulations.

Preliminary results from this work have been presented previously in abstract form (Fukuda et al., 2002). 
Nestin gene

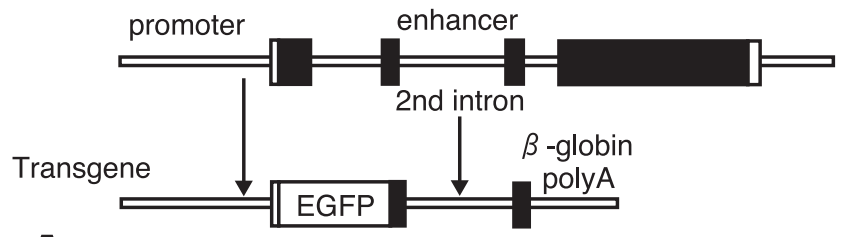

A
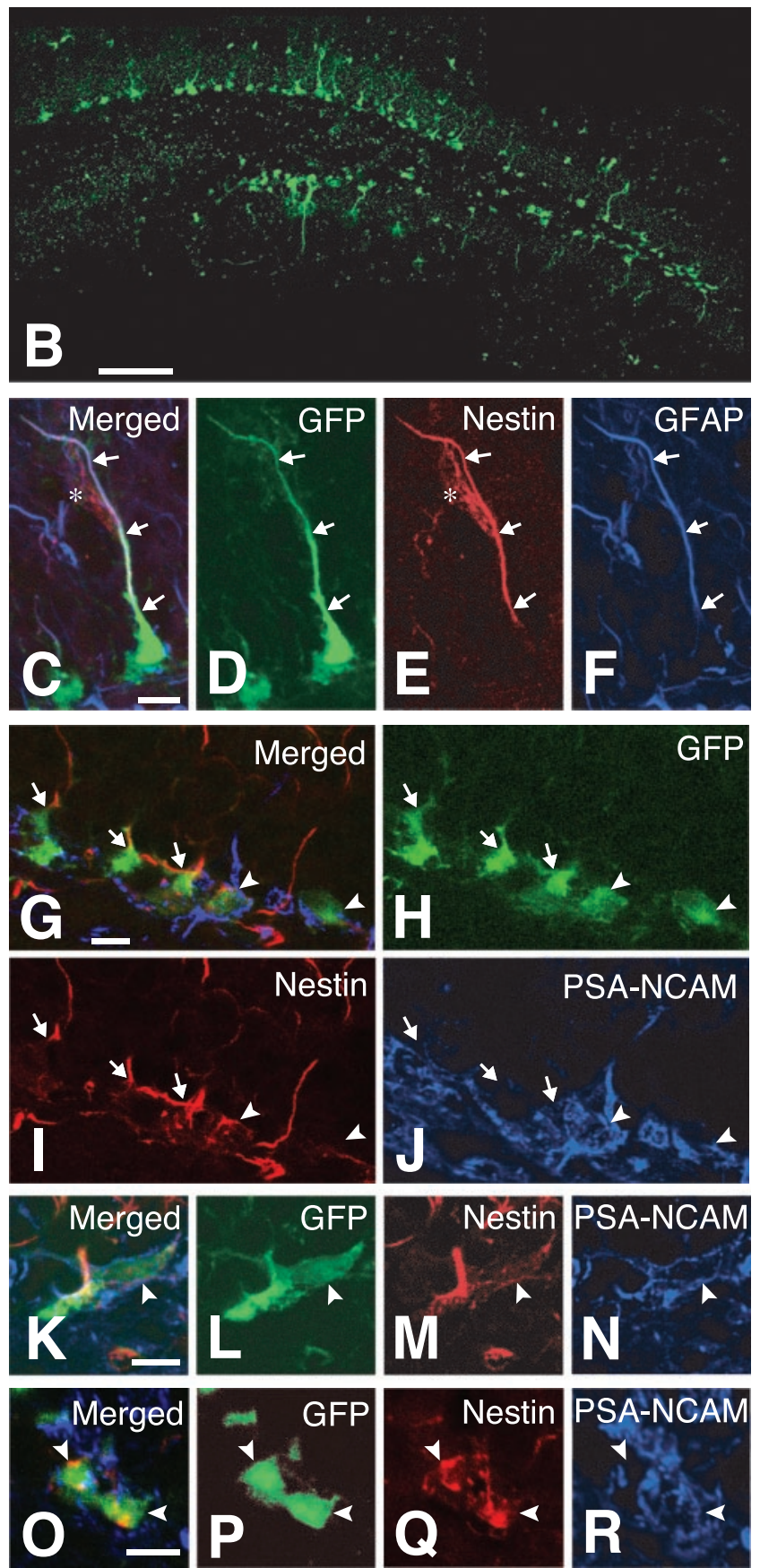

Figure 1. GFP-expressing cells in the dentate gyrus of adult nestin promoter-GFP mice. $A$, Structure of nestin promoter-GFP transgene. The nestin promoter-GFP transgenic mouse expressed GFP under the regulatory element of nestin promoter and the second intron. $B$, The dentate gyrus of the nestin promoter-GFP mouse observed with the aid of a confocal microscope. $C-F$, The nestin immunostaining to the GFP-expressing cells with the process bearing GFAP. C, Merged image. D, GFP fluorescence; $E$, immunostaining for nestin; $F$, immunostaining for GFAP. The cell expressing nestin also expressed GFAP (arrows) and often comes in contact with blood vessels, which were also positively stained with anti-nestin ( $E$; asterisk) as described

\section{Materials and Methods}

Animals. Nestin promoter-GFP transgenic mice were constructed by ligation of enhanced GFP cDNA (Clontech, Palo Alto, CA) with the nestin promoter region and the enhancer region of the nestin gene spanning the $3^{\prime}$ part of the second exon to the $5^{\prime}$ part of the third intron and the rabbit polyadenylation site (see Fig. 1A) (Yamaguchi et al., 2000). Because we required a more intense GFP signal from the transgene to identify adult nestin-positive cells in acute hippocampal slices, we therefore used nestin promoter-GFP ${ }^{+/+}$(homozygote) mice. The age of mice used was from 6 weeks to 3 months [5-bromo-2-deoxyuridine (BrdU) pulse-chase experiments] or 6 months (other experiments). The nestinGFP transgenic mice for BrdU pulse-chase experiments were injected with $15 \mathrm{mg} / \mathrm{ml} \mathrm{BrdU}$ (Wako, Osaka, Japan) dissolved in $0.9 \% \mathrm{NaCl}$ with $7 \mathrm{~mm} \mathrm{NaOH}$ (final dose of $50 \mu \mathrm{g} / \mathrm{gm}$ body weight). All studies were performed in accordance with the Guidelines for Animal Experiments of the Graduate School of Frontier Sciences, University of Tokyo.

Immunohistochemistry. The nestin-GFP mice were perfused with saline and $4 \%$ paraformaldehyde in PBS (in mM: $137 \mathrm{NaCl}, 8.1 \mathrm{Na}_{2} \mathrm{HPO}_{4}$ $2.68 \mathrm{KCl}, 1.47 \mathrm{KH}_{2} \mathrm{PO}_{4}$ ). Brains were postfixed at $4^{\circ} \mathrm{C}$ overnight in $4 \%$ paraformaldehyde in PBS and then kept at $4{ }^{\circ} \mathrm{C}$ for a few days in $30 \%$ sucrose in Tris-buffered saline (TBS) (in mM: $137 \mathrm{NaCl}, 2.68 \mathrm{KCl}, 25$ Tris). They were then embedded in OCT compound (Sakura, Tokyo, Japan) and cut by a cryostat (MICRON, Walldorf, Germany) into $40 \mu \mathrm{m}$ sections. The slices were washed with TBS, pretreated with $0.5 \%$ Triton $\mathrm{X}-100$ in TBS (Triton-TBS) for $30 \mathrm{~min}$, and then blocked with blocking buffer ( $3 \%$ normal goat serum in $0.1 \%$ Triton-TBS) for $2 \mathrm{hr}$. Freefloating sections were incubated for $3 \mathrm{~d}$ at $4^{\circ} \mathrm{C}$ with rabbit polyclonal anti-nestin antibody (\#130, rabbit-IgG, 1:200 dilution; a generous gift from Dr. Ron McKay, National Institute of Neurological Disorders and Stroke, Bethesda, MD) (Blümcke et al., 2001), mouse monoclonal antipolysialylated neural cell adhesion molecule (PSA-NCAM) antibody (12E3, mouse-IgM, 1:500 dilution; a generous gift from Dr. T. Seki, Juntendo University School of Medicine, Tokyo, Japan) (Seki and Arai, 1993; Seki 2002) and mouse monoclonal anti-glial fibrillary acidic protein (GFAP) antibody (mouse IgG; 1:200 dilution; Sigma, St. Louis, MO) After being washed in TBS, sections were incubated with rhodamineconjugated anti-rabbit IgG antibody (1:200 dilution; Chemicon, Temecula, CA), Cy5-conjugated goat anti-mouse IgM antibody (1:200 dilution; ICN, Costa Mesa, CA), and Cy5-conjugated anti-mouse IgG antibody (1:200 dilution; Jackson ImmunoResearch, West Grove, PA) and mounted with Immu-mount (Shandon, Pittsburgh, PA). Stained sections were analyzed with a confocal microscope (TCS SP2; Leica, Wetzlar, Germany) (Koketsu et al., 2003). For BrdU staining, the sections were incubated with $10 \mathrm{~mm}$ citric acid buffer at $90^{\circ} \mathrm{C}$ for $5 \mathrm{~min}$. The heated sections were left at room temperature for $30 \mathrm{~min}$ and washed with TBS for $10 \mathrm{~min}$. The sections were incubated in $1 \mathrm{M} \mathrm{HCl}$ at $37^{\circ} \mathrm{C}$ for $30 \mathrm{~min}$, neutralized by rinsing with $0.1 \mathrm{~m}$ borate buffer, and washed with TBS. In addition to the above-mentioned first antibody, we used rat monoclonal anti-BrdU antibody (mouse IgG; 1:200 dilution; Harlan, Leicestershire, UK), rabbit polyclonal anti-GFP antibody (rabbit IgG 1:1000 dilution; Molecular Probes, Eugene, OR), and mouse monoclona anti-neuronal nuclei (NeuN) antibody (mouse IgG, 1:1000 dilution; Chemicon). For detection of the first antibody, rhodamine-conjugated anti-rat IgG antibody (1:200 dilution; Jackson ImmunoResearch), Alexa488-conjugated anti-rabbit IgG antibody (1:1000 dilution; Molecular Probes), and 7-amino-4-methylcoumarin-3-acetic acid (AMCA)conjugated anti-mouse IgG antibody (1:200 dilution; Chemicon) were used.

Preparation of acute living slice. The nestin promoter-GFP transgenic mice used in the experiments were deeply anesthetized with ketamine

\section{$\leftarrow$}

previously (Palmer et al., 2000), but this blood vessel did not express GFP signal. $G-R$, The three sets of the confocal image $(G-J, K-N$, and $0-R)$ demonstrating the nestin immunostaining to the GFP-expressing cells bearing PSA-NCAM proteins at their cell surface (arrowheads). The merged image is shown in $G, K, 0$; GFP fluorescence is shown in $H, L$, $P$; the immunostaining for nestin protein is shown in $I, M, Q$; the immunostaining for PSA-NCAM is shown in $J, N, R$. Note that the cell surface areas of PSA-NCAM-bearing GFP-positive cells were positively stained with this anti-nestin antibody. Scale bars: $B, 100 \mu \mathrm{m} ; C-R, 10 \mu \mathrm{m}$. 

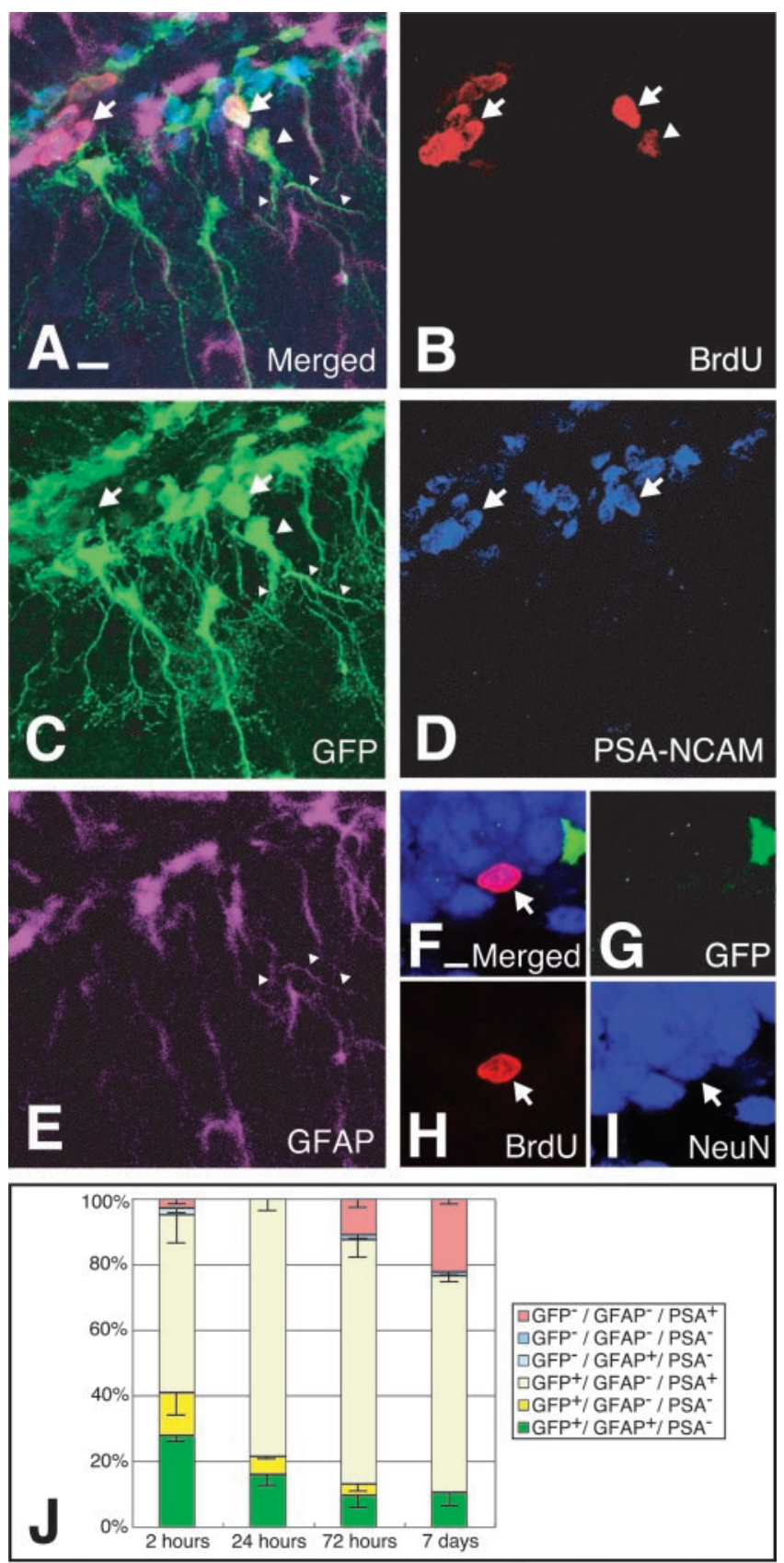

Figure 2. The BrdU pulse-chase examination on nestin-GFP transgenic mouse. $A$, The GFPpositive cell labeled with BrdU at the $2 \mathrm{hr}$ time point. $B-E$, Separate image of $A . B$, Immunostaining for BrdU observed with rhodamine-conjugated anti-rat lg $G$ antibody; $C$, immunostaining for GFP observed with Alexa488-conjugated anti-rabbit antibody; $D$, immunostaining for PSA-NCAM observed with Cy5-conjugated anti-mouse IgM antibody; $E$, immunostaining for GFAP observed with AMCA-conjugated anti-mouse lgG antibody. $\mathrm{BrdU}^{+} / \mathrm{GFP}^{+} / \mathrm{GFAP}^{-} / \mathrm{PSA}-$ $\mathrm{NCAM}^{+}$cells are indicated with arrows. BrdU ${ }^{+} / \mathrm{GFP}^{+} / \mathrm{GFAP}^{+} / \mathrm{PSA}^{-N_{C A M}}{ }^{-}$cells are indicated with arrowheads. F, A BrdU-labeled cell stained with a neuronal marker, NeuN (arrow), did not express GFP protein at the $7 \mathrm{~d}$ time point. NeuN was stained with Cy5-conjugated anti-mouse Ig antibody.J, Percentage of BrdU-labeled cells in the subgranular zone at the time point 2, 24,72 hr, and $7 \mathrm{~d}$ after BrdU injection; 144 cells from three animals (48 per each animal) were calculated for each group. In J, error bars indicate SE. Scale bars: $A, 10 \mu \mathrm{m} ; F, 5 \mu \mathrm{m}$.

(100-150 mg/kg, i.p.) before decapitation. Brains were removed rapidly and placed in ice-cold low-calcium artificial CSF (ACSF) containing (in mM): $125 \mathrm{NaCl}, 2.5 \mathrm{KCl}, 0.1 \mathrm{CaCl}_{2}, 5 \mathrm{MgCl}_{2}, 1.25 \mathrm{NaH}_{2} \mathrm{PO}_{4}, 0.4$ L-ascorbic acid, $25 \mathrm{NaHCO}_{3}$ (osmolarity $320 \mathrm{mOsm} / \mathrm{kg}$; pH 7.4 when saturated with $\left.95 \% \mathrm{O}_{2}-5 \% \mathrm{CO}_{2}\right)$. For each experiment, the brain was glued to the cutting stage of a vibrating slice cutter (DTK-1000, Dosaka,
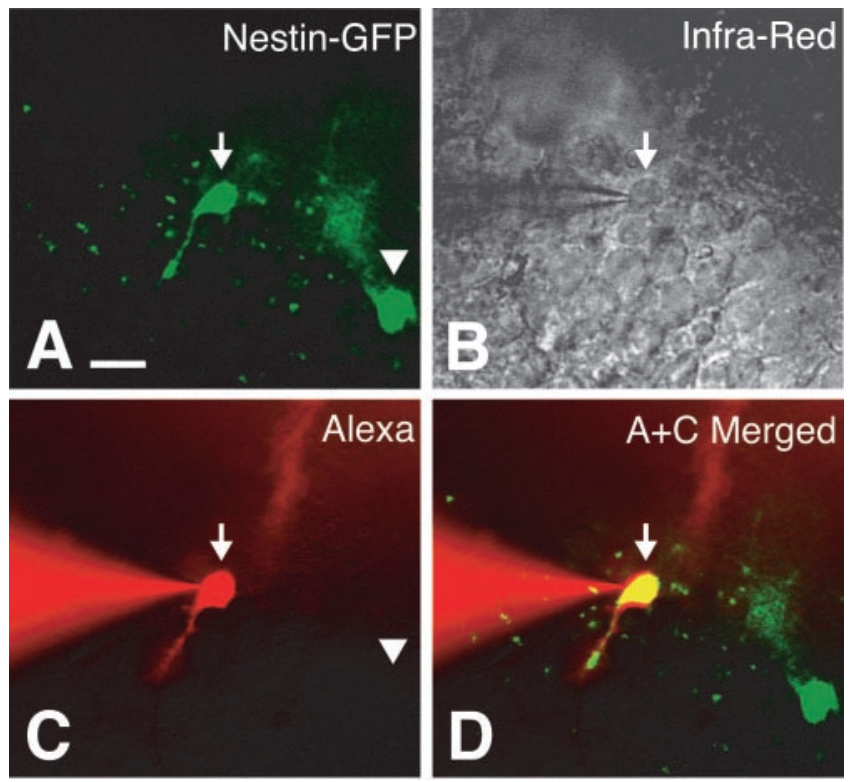

Figure 3. Visually guided patch-clamp recording from a cell expressing GFP in the adult DG of a nestin promoter-GFP mouse. A, Visual identification of a cell expressing GFP (arrow and arrowhead). $B$, Infrared DIC image of the slice. The cell in the center (arrow) was identified as GFP positive in $A$, and a patch pipette (seen from the left) was guided to the cell to establish the whole-cell configuration. C, Fluorescence image using the dye Alexa Fluor 568, which was spontaneously perfused from the patch pipette into the cell under recording. The wavelength of the excitation light used for the Alexa 568 was $\sim 568 \mathrm{~nm}$, and emission was in the red. Note that the emitted fluorescence signal is absent in another GFP-positive cell that was not patch clamped (arrowhead).D, Overlapped image of $A$ and (certifying that the patch-clamp recording was made from a GFP-positive cell. Scale bar, $10 \mu \mathrm{m}$.

Kyoto, Japan) with the rostral side up and sliced into coronal sections $(400 \mu \mathrm{m})$ that included the hippocampus. The slices were incubated in standard ACSF containing (in mM): $125 \mathrm{NaCl}, 2.5 \mathrm{KCl}, 2 \mathrm{CaCl}_{2}, 1.3$ $\mathrm{MgCl}_{2}, 1.25 \mathrm{NaH}_{2} \mathrm{PO}_{4}, 12.5$ D-glucose, 0.4 L-ascorbic acid, $25 \mathrm{NaHCO}_{3}$ (saturated with $95 \% \mathrm{O}_{2}-5 \% \mathrm{CO}_{2}$ ) for $30-40 \mathrm{~min}$ at $37^{\circ} \mathrm{C}$ and then maintained at room temperature until recordings were performed (Miyakawa et al., 2002). One slice was fixed in a recording chamber $(\sim 0.2 \mathrm{ml}$ volume, RC-26GLP; Warner Instruments, Hamden, CT) under nylon strings attached to a U-shaped platinum frame and then submerged in, and continuously perfused with, the standard ACSF at a flow rate of 1-2 $\mathrm{ml} / \mathrm{min}$ (Kato and Shigetomi, 2001). The GFP-positive cells in the hippocampus were observed with the aid of a fluorescence microscope (BX50WI, Olympus, Tokyo, Japan) and visualized with a chilled chargecoupled device (CCD) video camera (C5985, Hamamatsu, Hamamatsu, Japan). After identification of the GFP signals, the light path of the microscope was switched to the infrared differential interference contrast (infrared DIC) optics mode. Infrared DIC images were monitored on a video monitor, which allowed visual guidance of the patch electrode (see below), and stored on the computer as image files together with a GFPfluorescence image (XL-20, Olympus) for morphological analyses and identification of the location of the recorded neuron.

Whole-cell transmembrane current recordings. Patch electrodes were fabricated from borosilicate glass capillaries of $1.2 \mathrm{~mm}$ outer diameter (1B120F-4, World Precision Instruments, Sarasota, FL) with a programmable puller (P-87, Sutter Instrument, Novato, CA). The composition of the pipette internal solution was (in $\mathrm{mM}$ ): 120 potassium gluconate, 6 $\mathrm{NaCl}, 5 \mathrm{CaCl}_{2}, 2 \mathrm{MgCl}_{2}, 2 \mathrm{MgATP}, 0.3 \mathrm{NaGTP}, 10$ EGTA, 10 HEPES, pH 7.2 with $\mathrm{KOH}$. The intracellular solution also included Lucifer yellow dilithium salt [0.5\%; Sigma) or Alexa Fluor 568 hydrazide sodium salt (0.5\%; Molecular Probes)] for visual identification of the cells recorded. The tip resistance of the electrodes ranged from 5 to $10 \mathrm{M} \Omega$ when filled with this solution. After establishment of the cell-attached configuration (1-10 G $\Omega$ seal resistance), the whole-cell mode was established with negative pressure and negative current pulses using a DigiData 1200 


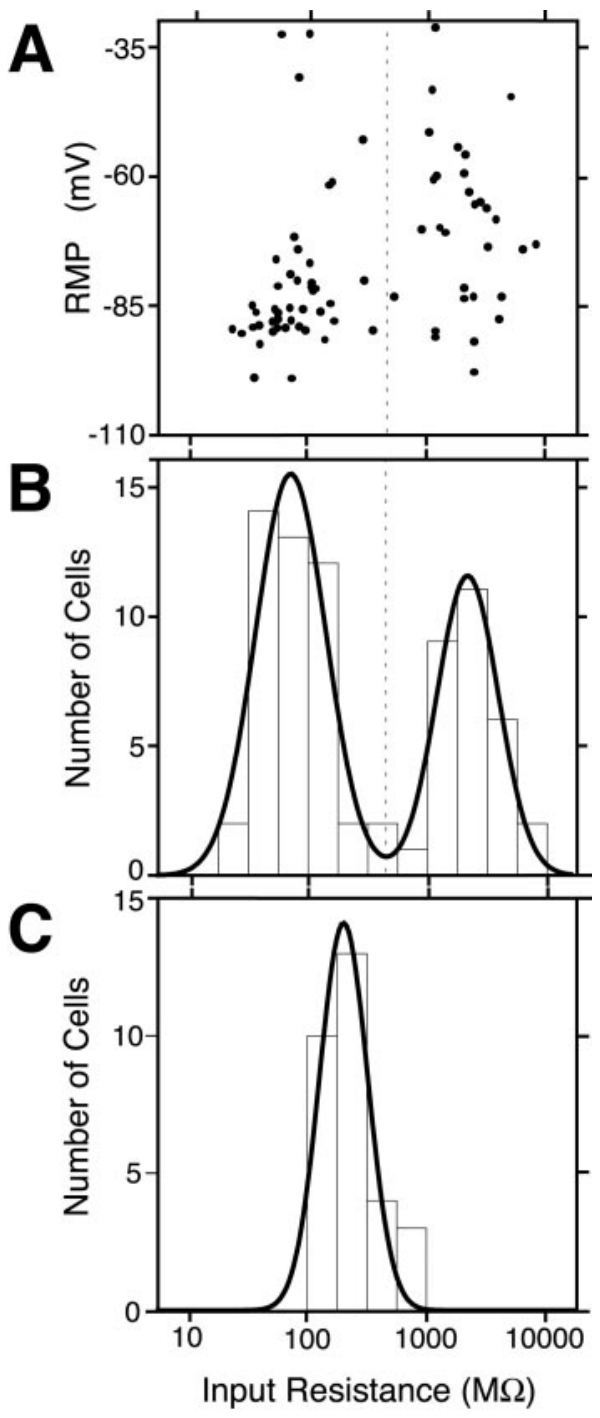

Figure 4. Bimodal distribution of input resistance in nestin-GFP-positive cells. A, Relationship between IR and RMP. Abscissa, IR in logarithmic scale; ordinate, RMP. Plot of results from a total of 74 GFP-positive cells. B, Distribution of IR of GFP-positive cells. Ordinate, number of cells. Abscissa, IR (same as $A$ ). The curve indicates the result of a nonlinear, least squares curve fitting of a double Gaussian distribution. The vertical broken line indicates the trough between two Gaussian peaks at $\sim 500 \mathrm{M} \Omega$. C, Distribution of IR for GFP-negative mature neurons in the DG.

interface (Axon Instruments, Foster City, CA) controlled by a pCLAMP6 (Axon Instruments) program. The IR and resting membrane potential (RMP) were measured immediately after rupture of the patch membrane to avoid possible changes in the membrane properties attributable to cytoplasmic perfusion with the pipette solution. The IR was calculated by measuring the steady-state passive current evoked with a hyperpolarizing pulse of $5 \mathrm{mV}$ amplitude and $10 \mathrm{msec}$ duration repeated every $40 \mathrm{msec}$ under voltage-clamp mode from a holding potential of $-70 \mathrm{mV}$ (see Fig. $5 A, B)$. The IR value measured by this $10 \mathrm{msec}$ pulse was comparable with the IR value estimated by the longer $(600 \mathrm{msec})$ pulse measurement $(p<$ $0.001 ; n=20$ ), in which the value of IR was estimated using the two current values at the end of -40 and $-50 \mathrm{mV}$ voltage holds (see Fig. $5 C, D)$. The averaged values of series resistance on "type I" and "type II" as measured by the pCLAMP6 membrane test mode were $13.9 \pm 1.4 \mathrm{M} \Omega$ $(n=10$; mean \pm SE) and $14.4 \pm 0.3(n=10)$, respectively. The series resistance and membrane capacitance were not compensated in all the recording.

RMPs were measured by switching the amplifier to the current-clamp mode with no current injection. The liquid junction potentials were $\sim 10$ $\mathrm{mV}$ as calculated with Clampex 8.2 (Axon Instruments), and then all membrane potentials were appropriately corrected. Cells with an RMP above $-30 \mathrm{mV}$ were rejected.

Data were recorded at room temperature with an Axopatch 200B patch-clamp amplifier (Axon Instruments) or with a CEZ-2400 amplifier (Nihon-kohden, Tokyo, Japan). The membrane current was sampled on-line at $4 \mathrm{kHz}$ (PowerLab, AD Instruments, Grand Junction, $\mathrm{CO}$ ) after filtering at $2 \mathrm{kHz}$ and stored on the hard disk of a personal computer. The data were analyzed off-line with "Igor Pro 4.01" (WaveMetrics, Lake Oswego, OR). External test solution was made up in standard ACSF and often was included with $1 \mathrm{~mm} 4$-aminopyridine (4-AP) (Sigma) or $1 \mu \mathrm{M}$ tetrodotoxin (TTX) (Wako).

Immunostaining for recorded slices. After recording, some slices were postfixed at $4^{\circ} \mathrm{C}$ overnight in $4 \%$ paraformaldehyde in TBS and then kept at $4^{\circ} \mathrm{C}$ for a few days in $30 \%$ sucrose in TBS. The slices were washed with TBS, pretreated with $0.5 \%$ Triton X-100 in TBS for $30 \mathrm{~min}$, and then blocked with blocking buffer. Free-floating sections were incubated for $3 \mathrm{~d}$ at $4^{\circ} \mathrm{C}$ with PSA-NCAM antibody or GFAP antibody as mentioned above.

\section{Results}

GFP-positive cells in adult DG from nestin-GFP mice can be classified into two subpopulations

In a previous study, we described that nestin promoter-GFP transgenic mice exhibited a large number of GFP-positive cells within the subgranular zone of the adult hippocampal DG (Fig. 1 ), and these GFP-positive cells were stained with GFAP or PSANCAM (Yamaguchi et al., 2000). In this communication, we first confirmed that both types of nestin-GFP-positive cells would express nestin protein. For this purpose, we used polyclonal antinestin antibody (\#130), which was kindly provided by Dr. Ron McKay (Blümcke et al., 2001).

As shown in Figure $1 C-F$, the process of the GFP-positive cell bearing GFAP-positive process was stained strongly by this antinestin antibody. Similar staining has been observed in most of the GFP-positive cells bearing GFAP (Fig. 1G-J, arrows). On the other hand, the nestin immunoreactivity to the GFP-positive cell bearing the PSA-NCAM molecules was relatively weak and limited to the surface of its cell membrane. We showed several examples of this type of staining (Fig. $1 G-R$ ). As shown in Figure $1 G-J$, the cell surface of GFP-positive cells bearing PSA-NCAM including their proximal process was stained significantly by this anti-nestin antibody. The level of GFP signal was relatively weaker than that of surrounding PSA-NCAM-negative GFPpositive cells, presumably GFP-positive cells bearing GFAP, suggesting decreased nestin-promoter activity in GFP-positive cells bearing PSA-NCAM. Figure $1 K-R$ demonstrates three other examples of the cell surface expression of nestin proteins in GFPpositive cells bearing PSA-NCAM. We performed such a nestin staining study very extensively and could conclude that GFPpositive cells bearing PSA-NCAM express nestin protein to a significant level. The set of nestin staining data strongly suggests that GFP expression in nestin-GFP transgenic mice would correspond to the expression of nestin protein in adult DG.

Because nestin-positive cells can be distinguished on the basis of GFAP or PSA-NCAM expression, we evaluated whether one or both cell types are active in the process of neurogenesis. Figure $2 A-E$ shows a four-color immunostaining for distinguishing each cell type $\left(\mathrm{GFAP}^{+}\right.$vs PSA-NCAM $\left.{ }^{+}\right)$in the BrdU pulse-chase experiments (Fig. $2 \mathrm{~J}$ ). At $2 \mathrm{hr}$ after BrdU injection, the frequency of $\mathrm{GFP}^{+} / \mathrm{GFAP}^{+} / \mathrm{PSA} \mathrm{NCAM}^{-}$in total BrdU ${ }^{+}$cells was $27.7 \%$, whereas $54.2 \%$ of $\mathrm{BrdU}^{+}$cells was $\mathrm{GFP}^{+} / \mathrm{GFAP}^{-} / \mathrm{PSA}^{-}$ $\mathrm{NCAM}^{+}$. In this analysis, we also observed $\mathrm{BrdU}^{+} / \mathrm{GFP}^{+} /$ $\mathrm{GFAP}^{-} / \mathrm{PSA}^{-\mathrm{NCAM}^{-}}{ }^{-}$cells, and the frequency was $13.2 \%$. At 24 $\mathrm{hr}$ after BrdU injection, the percentage of $\mathrm{GFP}^{+} / \mathrm{GFAP}^{+} / \mathrm{PSA}-$ $\mathrm{NCAM}^{-}$cells decreased to $15.9 \%$, while that of $\mathrm{GFP}^{+} / \mathrm{GFAP}^{-}$/ 
Type I

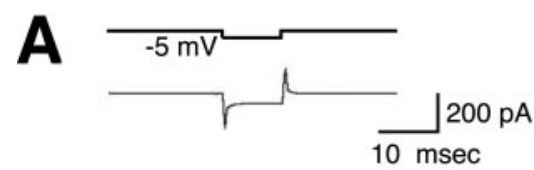

C
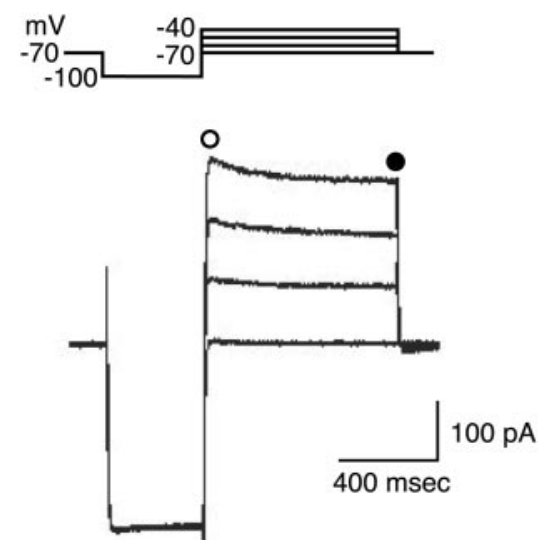

E

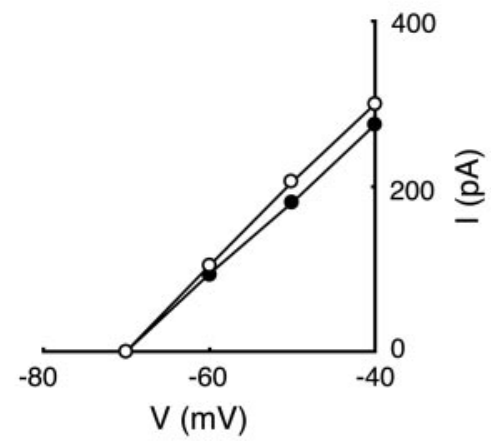

Type II

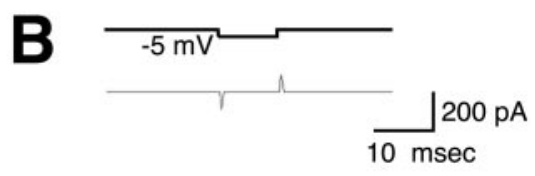

D
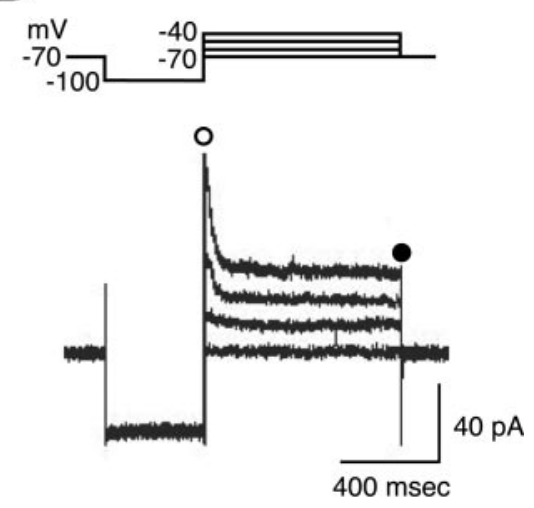

$\mathbf{F}$

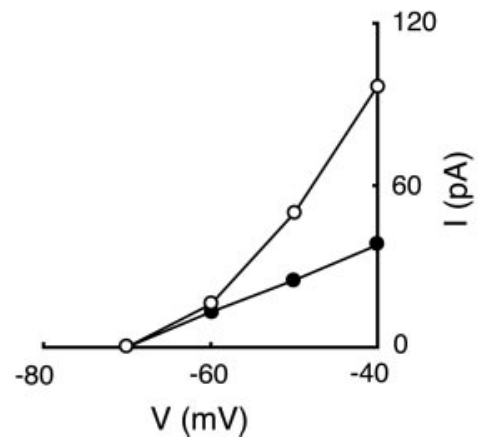

Figure 5. Electroresponsiveness of type I (lower IR) and type II (higher IR) GFP-positive cells in the DG. A, C, E, Results from type I cells; $B, D, F$, results from type II cells. $A, B$, Measurement of IR with a $-5 \mathrm{mV}$ square voltage pulse (above) from a holding potential around $-70 \mathrm{mV}$. The steady-state current at the end of the hyperpolarizing command pulse was measured. Current traces (below) are averages of the responses to 100 consecutive pulses. $C, D$, Responses to a voltage step pulse indicated at the top of the panel. Four current traces are superimposed for each panel. Note that the vertical scales are different between $C$ and $D . E, F$, Plot of the transmembrane current (ordinates) elicited by the voltage step pulses shown in ( and $D$ against the command voltage (abscissas). Open circles represent the values at the peak of the outward current $(C, D)$; filled circles indicate the steady-state current values $(C, D)$.

PSA-NCAM ${ }^{+}$cells increased to $78.5 \%$. At $72 \mathrm{hr}$ after BrdU injection, the percentage of $\mathrm{GFP}^{+} / \mathrm{GFAP}^{+} / \mathrm{PSA} \mathrm{NCAM}^{-}$cells still decreased to $9.7 \%$. These results strongly suggested cell differentiation from $\mathrm{GFAP}^{+} / \mathrm{PSA}^{-\mathrm{NCAM}^{-}}$nestin-positive "early progenitors" to GFAP ${ }^{-} / \mathrm{PSA}_{\mathrm{NCAM}}{ }^{+}$nestin-positive "late progenitors" in adult dentate gyrus. Neuronal differentiation of nestin-positive progenitors was subsequently analyzed with antiNeuN staining of $\mathrm{BrdU}^{+}$cells. $\mathrm{BrdU}^{+} / \mathrm{NeuN}^{+}$cells first appeared at $72 \mathrm{hr}$ after BrdU injection. At $7 \mathrm{~d}$ after BrdU injection, NeuN staining was observed in $\mathrm{BrdU}^{+} /$nestin-GFP ${ }^{-}$cells (Fig. $2 F-I$ ), and its proportion was $20 \%$. Taken together, these results may indicate that nestin ${ }^{+} / \mathrm{GFAP}^{+} / \mathrm{PSA}^{-\mathrm{NCAM}^{-}}$early progenitors would differentiate into nestin ${ }^{+} / \mathrm{GFAP}^{-} / \mathrm{PSA}^{-\mathrm{NCAM}^{+}}$late progenitors and then produce newborn neurons at adult DG.

Patch-clamp recordings of whole-cell membrane currents from visually identified GFP-positive cells were performed. Fig- ure 3 illustrates how selective recording from GFP-positive cells was made. GFPpositive cells were identified (Fig. 3A) by observing their fluorescence signals displayed on a video monitor. The optical path was then changed to infrared DIC (Fig. 3B), which permitted the tip of the patch electrode to be positioned on the cell body of a GFP-positive cell (Fig. 3B, arrow). After establishment of the whole-cell configuration, the intracellular solution in the patch pipette spontaneously and gradually perfused into the cytoplasm of the cell, which was confirmed by observing the fluorescence signal of the hydrophilic fluorescent dye in the patch pipette solution emanating from the tip of the patch electrode and filling the cell (Alexa Fluor 568 in the case of Fig. $3 C$ ). In this way, we confirmed the patch recording of the GFPpositive cells from the observation that the cell shape visualized with injected fluorescence dye exactly overlapped with the shape from GFP signal (Fig. 3D).

Immediately after the establishment of the whole-cell configuration, the IR and RMP were measured (Fig. $4 A$ ). The IR of GFP-positive cells was extremely variable, ranging from 22.6 to $8460 \mathrm{M} \Omega$. Interestingly, the distribution of the IR for these cells was clearly bimodal (Fig. $4 B$ ). When the number of cells was plotted as a function of the logarithmic value of IR (Fig. $4 B$ ), the resulting frequency histogram could be fit with a double Gaussian distribution with two distinct peaks (Fig. $4 B$, solid line). The estimated value of the two Gaussian peaks was $10^{(1.86 \pm 0.42)(\mu \pm \sigma)}$ $\mathrm{M} \Omega$ for the left peak and $10^{(3.34 \pm 0.36)} \mathrm{M} \Omega$ for the right peak. A statistic indicates that these Gaussian peaks are independent $(p<0.05$; Student's $t$ test), thus showing that the nestin-positive cells can be classified into two distinct subpopulations on the basis of their IR. These Gaussian peaks were also significantly $(p<0.05$; Student's $t$ test) different from the Gaussian peak fit to the IR distribution for mature GFP-negative neurons recorded from the same slices (Fig. $4 C)\left(10^{(2.31 \pm 0.29)} \mathrm{M} \Omega ; n=30\right.$ cells). In effect, the two peaks of the IR distribution split at $\sim 500$ $\mathrm{M} \Omega$. The RMPs (Fig. $4 A$, ordinate) of the cells belonging to the two distinct peaks in the IR distribution were significantly different $[-80.4 \pm 2.3$ and $-69.7 \pm 2.9 \mathrm{mV}$ (mean $\pm \mathrm{SE}$ ) for the cells with smaller IR and larger IR, respectively; $p<0.05$; Student's $t$ test] (Fig. 4A). On the basis of these results, we termed the cells with smaller IR $(<500 \mathrm{M} \Omega)$ as type I cells and those with larger IR $(>500 \mathrm{M} \Omega$ ) as type II cells. The geometric mean for the recorded IR data of type I cells was 77.1 $\mathrm{M} \Omega$ (refer to $10^{(1.89 \pm 0.27)(\text { mean } \pm S D)}$ $\mathrm{M} \Omega$ from $n=44)$. This value is significantly smaller than that of type II cells ( $2110 \mathrm{M} \Omega$; refer to $10^{(3.32 \pm 0.27)} \mathrm{M} \Omega$ from $n=30$ ) ( $p<0.001$; Student's $t$ test), again indicating that these subpopulations of GFP-positive cells belong to distinct groups of cells. The ratio of cell numbers between type I and type II cells shown above 
may not correctly reflect the actual proportion of these cell types in the adult DG, for the ease of giga-seal formation depends on the cell type. In this recording study, we were able to exclude data from vascular endothelial cells, which occasionally express nestin-GFP signal (data not shown), from the two criteria. The vascular endothelial cells can be easily identified from their typical cell shape. Moreover, if recorded intentionally, the RMP of these cells was above $-20 \mathrm{mV}$ (data not shown), a value excluded from the present analyses (see Materials and Methods).

\section{Voltage-dependent membrane currents of type I and type II cells}

Figure 5 illustrates the results of further analyses of the electrophysiological characteristics of the GFP-positive cells. First, type I and type II cells were identified by measuring the passive current elicited by identical voltage steps (Fig. 5A,B). The steady-state current was used to estimate IR as plotted in Figure 4. Figure $5 C$ indicates that in the type I cell tested, a slowly inactivating outward current, reminiscent of the A-current, is expressed in response to depolarizing pulses (open circle) delivered after a prepulse to $-100 \mathrm{mV}$ from $-70 \mathrm{mV}$ for $400 \mathrm{msec}$. This outward current was activated at membrane potentials above $-60 \mathrm{mV}$ (Fig. 5E, open circles) and inactivated to reach a steady-state level at $800 \mathrm{msec}$ (Fig. 5C,E, closed circles). This outward conductance was observed in 25 of 31 type I cells. The component of voltage-activated outward current at -40 $\mathrm{mV}$ was mostly $[78.9 \pm 2.2 \%$ (mean \pm $\mathrm{SE}) ; n=4]$ inhibited by $1 \mathrm{~mm} 4$-AP, suggesting the presence of A-current in type I cells. In contrast, rapidly inactivating outward currents (Fig. 5D, open circle) was more pronounced in type II cells. This outward current was activated significantly above $-50 \mathrm{mV}$ and inactivated within $50 \mathrm{msec}$ (Fig. 5D,F). The same voltage step protocol elicited a very similar, rapidly inactivating outward current in four of five type II cells tested.

Contrary to our initial expectation when we started to record from GFP-positive cells in these transgenic mice, type I and type II cells presented neither spontaneous postsynaptic currents nor action potentials during depolarization (Fig. 6A,B) [for type I $(n=44)$ and type II $(n=30)$ cells, respectively]. This was not caused by the recording conditions because all GFP-negative mature granule neurons recorded in the same slices $(n=30)$ presented spontaneous postsynaptic currents (Fig. 6C) and action potentials. As shown in Figure $6 D$, no type I cells exhibited voltage-activated inward current $(n=14)$; however, type II cells showed voltage-activated inward current (Fig. $6 E$, arrowhead). This current was activated mostly at membrane potential -30 $\mathrm{mV}$. In 6 of 24 type II cells, we obtained "net" inward current exceed the holding current at $-80 \mathrm{mV}$, and the average of these six currents from the holding potential of $-80 \mathrm{mV}$ was $32.5 \pm$ $10.0 \mathrm{pA}$ (mean $\pm \mathrm{SE}$ ). These inward currents were completely blocked by the addition of TTX (Fig. 6E). In the GFP-negative mature neurons, the fast inward current was much larger (Fig. $6 F$, arrowhead). These observations clearly demonstrate that type II cells express functional voltage-dependent fast sodium conductance.

\section{Type I and type II nestin-positive cells in the adult DG have different morphological and immunohistochemical characteristics}

To evaluate the morphological features of GFP-positive cells in the DG in relation to the above classification, we measured the length of the principal process of nestin-GFP-positive cells. The process length of each cell is plotted against IR in Figure $7 \mathrm{~A}$. Interestingly, most type I cells had processes $>10 \mu \mathrm{m}$, whereas GFP-positive processes were rarely detected for type II cells (Fig. $7 \mathrm{~B}, \mathrm{C})$. The length of the process in type I cells was significantly longer than that of type II cells $(p<0.05$; Mann-Whitney $U$ test), indicating that these subgroups have distinct morphological characteristics.

The fluorescence of Lucifer yellow, which filled the cell during the whole-cell recording, was visualized using confocal microscopy. Type I cells had a triangular soma and a thick process ex- 

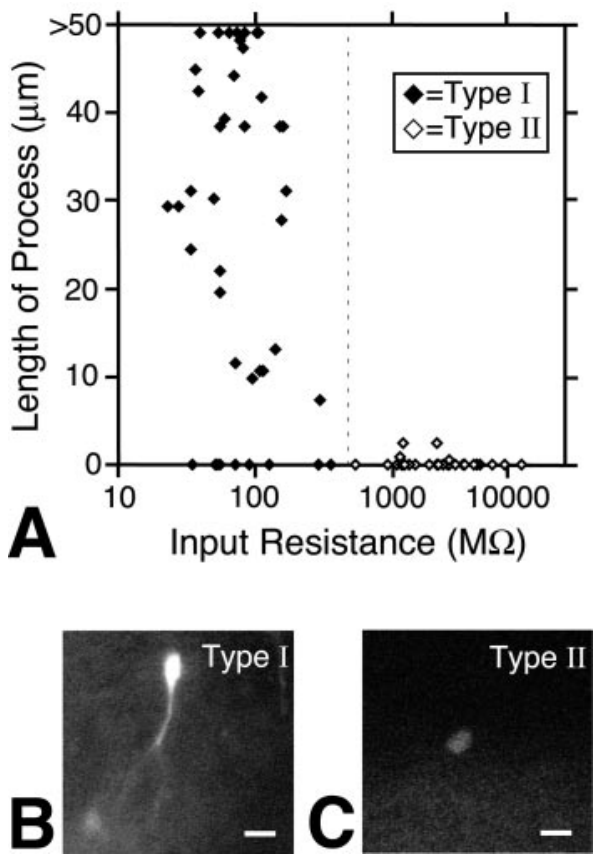

Figure 7. Relationship between process length and IR in GFP-positive cells. A, The length of the principal process with GFP signal was measured in all GFP-positive cells recorded using a fluorescence microscope with a high-sensitivity chilled CCD camera. Abscissa, IR in logarithmic scale; ordinate, process length. The maximum length was limited to $50 \mu \mathrm{m}$ because of the measurement on the TV monitor of the fluorescence-sensitive $C C D$ camera. Filled diamonds indicate data from type I cells; open diamonds indicate type II cells. B, C, Representative examples of the fluorescence image of a type I cell $(B)$ and a type II cell ( $C$. Note that the type I cell exhibits a process, whereas the type II cell does not. Also, note that the GFP fluorescence signal is weaker in type II cells, which was a commonly observed feature of these cells. Scale bar, $10 \mu \mathrm{m}$.

tending radially to the molecular layer, with several branching processes (Fig. $8 A, B$ ). These morphological properties are reminiscent of those reported for "residual radial glial cells" (Kosaka et al., 1986; Nacher et al., 2001a). In contrast, type II cells had a round soma and a very thin process (Fig. $8 C, D$ ) that were not visible in the GFP images. The direction of the type II cell process was opposite or tangential to the molecular layer of the DG. These morphological features of type I and type II cells were clearly different from those of mature astrocytes (Fig. $8 E$ ) and mature granule neurons (Fig. $8 F$ ) in the DG. Morphological properties highly similar to those described above were observed in nine type I and five type II cells in which a successful postfixation analysis was made after the patch-clamp recording.

In a limited number of patched cells, it was possible to immunohistochemically analyze the expression of specific markers in the cells identified to be type I or type II. Presumably because of a lack of cell-cell contact, the patched soma could usually be lifted from the slice during removal of the patch pipette in most of the cells tested, especially in the type II cells. As shown in Figure 9, all type I cells $(n=9 / 9)$ were stained with GFAP, and most of type II cells $(n=6 / 8)$ were stained with PSA-NCAM. These data indicate that type I and type II cells classified by the electrophysiological method correspond to the groups of GFAP-positive and PSANCAM-positive cells (Figs. 1, 2), respectively. The remaining type II cells ( $n=2$ of 8$)$ were not stained with PSA-NCAM, and

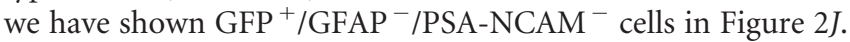
Therefore, $\mathrm{GFP}^{+} / \mathrm{GFAP}^{-} / \mathrm{PSA}^{-\mathrm{NCAM}^{-}}{ }^{-}$cells are probably classified into type II cells. These postfixation studies indicated that type I nestin-positive cells express GFAP proteins and type II nestin-positive cells start to express PSA-NCAM molecules.
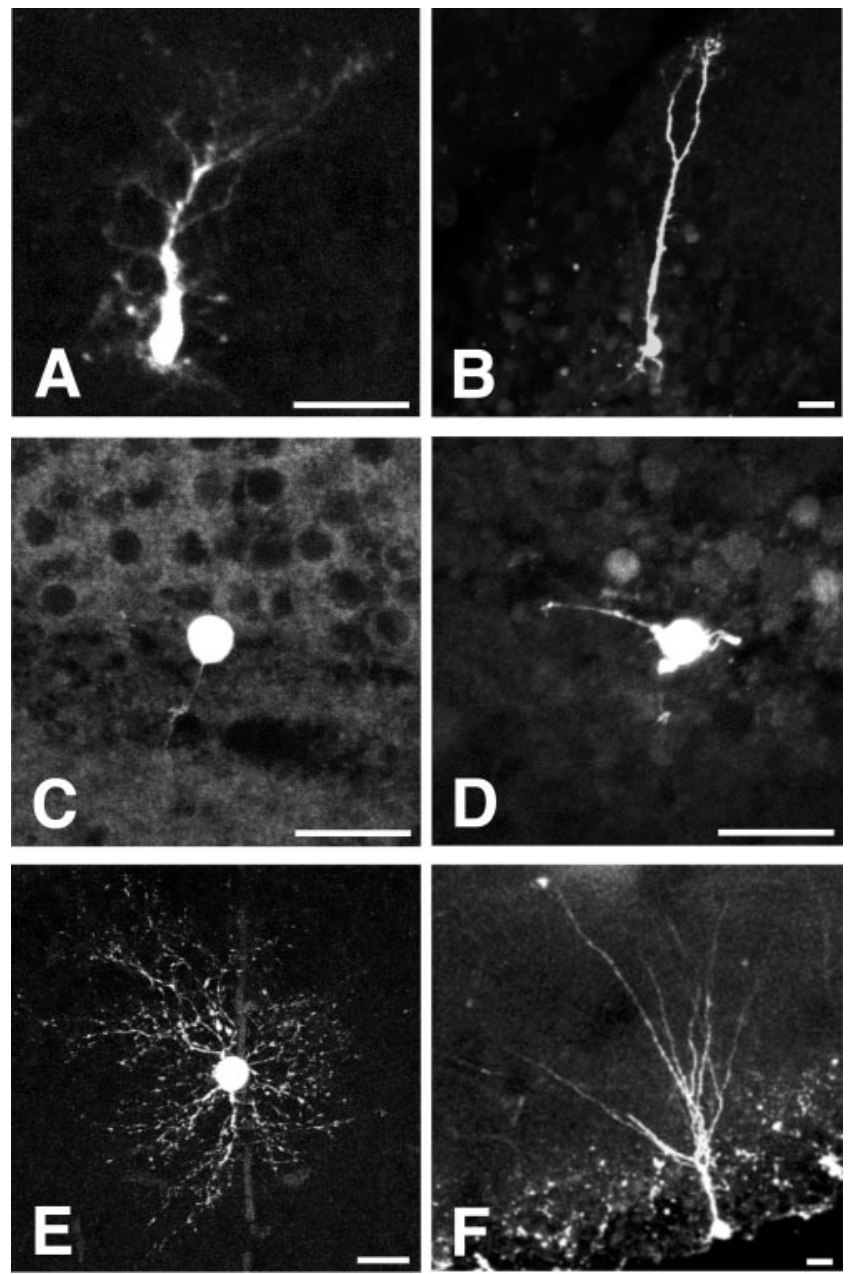

Figure 8. Morphological features of type I and type II nestin-expressing cells examined using fluorescence imaging after injection of Lucifer yellow into the cell during the whole-cell patchclamp recording. The slices were fixed after the recording, and the fluorescence was detected and visualized with a confocal scanning microscope. $A$, Type I cell; $B$, another type I cell; $C$, a type II cell; $D$, another type II cell; $E$, a GFP-negative typical astrocyte in dentate gyrus; $F$, a GFPnegative typical granule neuron in dentate gyrus. Note that type I cells ( $A$, a small type I cell; $B$, a large type I cell) always extended their principal process toward the molecular layer as same as granule neurons of dentate gyrus $(F)$, whereas the typical astrocytes extended their processes in all directions (Fig. 8E). Type II cells extended their processes to the opposite side of $(C)$ or tangentially to $(D)$ the granule cell layer. Scale bars, $15 \mu \mathrm{m}$.

\section{Discussion}

This study is the first demonstration of the physiological properties of nestin-positive precursor cells in living hippocampal slices from mature animals. Using hippocampal slices from mature transgenic nestin promoter-GFP mice (Yamaguchi et al., 2000), we have analyzed the electrophysiological properties and morphological characteristics of the nestin-expressing DG cells by selectively recording whole-cell membrane currents from GFPpositive cells. Recently, Kempermann et al. (2003) also used this nestin promoter-GFP mouse for the study on adult neurogenesis. In our study, we have first confirmed the validity of the visualization of immature precursor cells (Figs. 1,2).

The new findings of the present study can be summarized as follows (Fig. 10). (1) The nestin-positive cells can be classified clearly into two distinct subpopulations according to their difference in various phenotypes: type I and type II nestin-positive cells. (2) Type I cells presented a smaller IR (from 22.6 to 350 $\mathrm{M} \Omega$ ). On the other hand, type II cells presented a larger IR (from 

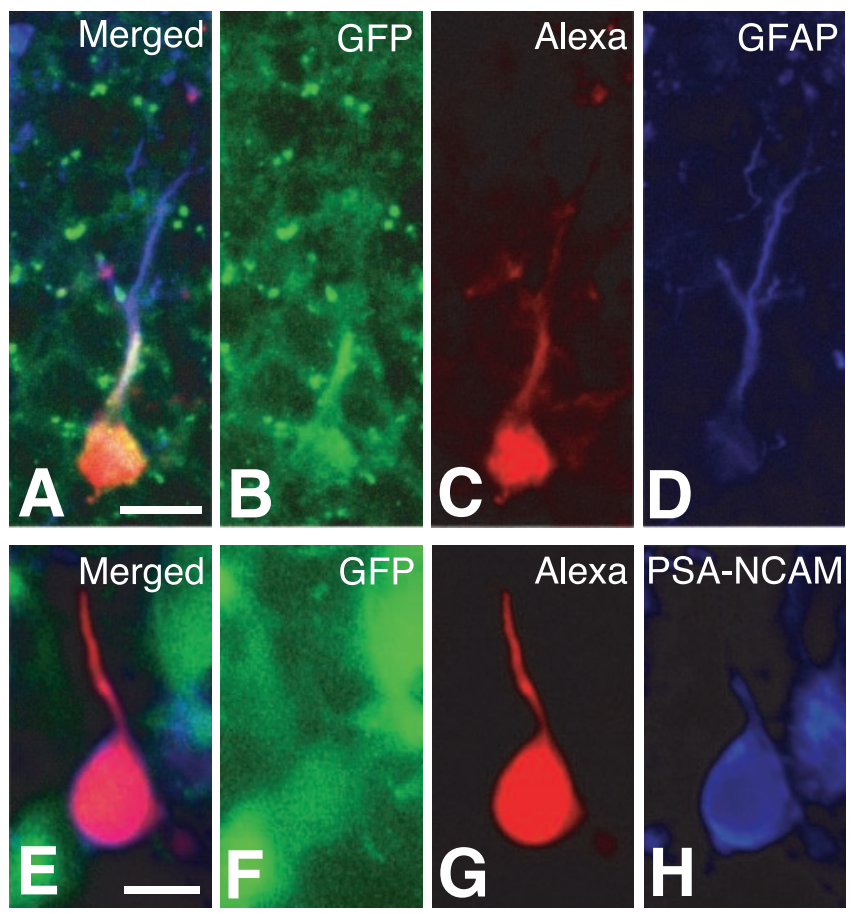

Figure 9. Expression of specific markers in type I and type II nestin-positive cells as confirmed by post-recording immunohistochemistry. Confocal microscopy images from slices in which a patch-clamp recording from a type I $(I R=36.0 \mathrm{M} \Omega)(A-D)$ and a type $\|(I R=910$ $\mathrm{M} \Omega)(E-H)$ cell was made. $A$, Merged image of the images shown in $B-D ; B$, GFP fluorescence; $C$, fluorescence image of Alexa Fluor 568 injected into the cell during whole-cell recording; $D$, immunostaining for GFAP observed with Cy5-conjugated anti-mouse lgG antibody, which was used to avoid cross-talk with other fluorescent emissions but shown in blue to demonstrate costaining with other dyes. $E$, Merged image of the images presented in $F-H ; F$, GFP fluorescence (note the fluorescence intensity of this type II cell is weaker than the surrounding GFPpositive cells); $G$, fluorescence image of Alexa Fluor 568 injected into the cell during whole-cell recording; $H$, immunostaining for PSA-NCAM. Scale bars: $A-D, 10 \mu \mathrm{m} ; E-H, 5 \mu \mathrm{m}$.

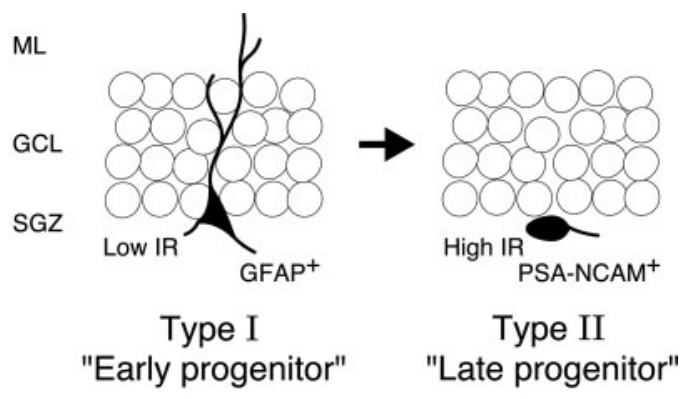

Figure 10. A schematic diagram illustrating the two types of nestin-positive progenitors at an early stage of neurogenesis in adult dentate gyrus. Cell morphology was on the basis of the images of the recorded cells injected with fluorescence dye (Figs. 8, 9). The BrdU pulse-chase analysis (Fig. 2) strongly suggested that GFAP ${ }^{+}$type I and PSA-NCAM ${ }^{+}$type II would be early and late progenitors for newborn neurons at adult DG. SGZ, Subgranular zone; GCL, granular cell layer; ML, molecular layer.

532 to $8460 \mathrm{M} \Omega$ ) and mostly exhibited depolarization-activated inward sodium current. (3) Type I cells were characterized by their longer processes toward the molecular layer, being stained with anti-GFAP, whereas most type II cells showed the expression of PSA-NCAM at their surface. (4) The BrdU pulse-chase analysis (Fig. 2) strongly suggested that type I and type II nestin-positive cells would be regarded as early progenitor and late progenitor, respectively. The key issue now, as discussed below, is the cellular identity of type I and type II cells and their role in adult neurogenesis.
The variation in the population of nestin-positive cells in the DG reflects variations in distinct differentiation stages during neurogenesis. In this context, we favor the view that type I cells as early progenitors are "radial glia-like" precursors that generate type II cells as late progenitors possessing some neuronal properties. The observation that the GFP signal of type II cells was generally weaker than other surrounding type I cells (Fig. 9) could support this scenario. It is reasonable to presume that early progenitor type I cells and late progenitor type II cells could be comparable with "B cells" and "D cells," which were named in the previous study (Seri et al., 2001). Seri et al. (2001) have also demonstrated that the proportion of B cells of BrdU-positive cells decreases dramatically at $24 \mathrm{hr}$ after BrdU injection, whereas that of D cells increases, indicating a rapid transition from $B$ cells to D cells. Our BrdU pulse-chase experiments have also strongly supported this theory: a rapid and dynamic shift from GFAP-positive early progenitors to PSA-NCAM-positive late progenitors.

By means of extensive double immunostaining with antiPSA-NCAM and anti-GFAP of DG of adult nestin promoter transgenic mice, we have observed few $(<1 \%)$ nestin-positive cells, which were stained with PSA-NCAM at a proximal site and seemed to possess $\mathrm{GFAP}^{+}$fiber at a distal site (data not shown). On the other hand, we detected many GFAP $^{-} / \mathrm{PSA}^{-\mathrm{NCAM}^{-}}{ }^{-}$, $\mathrm{BrdU}^{+}$nestin-positive cells. This type of cell is presumably classified into type II cell and is possibly in a transient state between $\mathrm{GFAP}^{+}$and PSA-NCAM ${ }^{+}$nestin-positive cells.

We subsequently discuss the phenotypes of type I nestinpositive cells and type II nestin-positive cells (see below). The type I cells were characterized by their relatively low IR (mean, 77.1 M ; range, 22.6-350 M $\Omega$ ). This range substantially overlaps that for recordings from DG astrocytes in hippocampal slices of adult rats (mean, $175 \mathrm{M} \Omega$; range, 119-278 M $\Omega$ ) (Bordey and Sontheimer, 2000), although, in the developmental stage, the IR of glial cells is relatively high (Kressin et al., 1995; Matthias et al., 2003). The relatively more negative RMP of type I cells in the present study suggests that the low IR is attributed to a larger resting potassium conductance as in the case of astrocytes (McKhann et al., 1997; Bordey and Sontheimer, 2000). In developing neocortex, radial glia cells have large conductance attributed their gap junction (Noctor et al., 2001), but this would be not the case in our study because the gap junction-permeable dyes Alexa and neurobiotin did not spread to other neighboring cells and the gap junction inhibitor halothane did not increase the value of IR in type I cells (data not shown). The expression of a depolarizationactivated, slowly inactivating outward current exclusively in type I cells is not inconsistent with the report by Bordey and Sontheimer (2000) who detected A-current-like outward currents in $82 \%$ of the DG astrocytes that they examined. In addition, the cells confirmed to be type I by patch-clamp recordings also costained with GFAP, thereby strongly supporting the notion that type I cells represent a subgroup of astroglia in the DG.

The shape of the type I cells, however, was not exactly the same as that of typical astrocytes. Rather, the morphological features of type I cells, such as radial GFAP-positive projections toward the molecular layer and a triangular soma, are quite similar to those of residual radial glia cells demonstrated in the adult DG (Kosaka and Hama, 1986; Alvarez-Buylla et al., 1987; Schmidt-Kastner and Szymas, 1990; Cameron et al., 1993; Seki and Arai, 1999). These radial glia cells with GFAP indeed express nestin (Fig. 1) (Nacher et al., 2001a). These types of radial glia are shown to be involved in the formation of the DG in rats and monkeys (Eckenhoff and Rakic, 1984; Rickmann et al., 1987) in a manner similar to the situation of neurogenesis in the developing neocortex. 
This suggests that type I cells might play a neuronal precursor role similar to that played by radial glia cells in cortical neurogenesis (Noctor et al., 2001). Seri et al. (2001) have shown, using the cell-specific integration of a retroviral vector, that GFAP-positive radial glia cells generate new neurons in the DG of adult rats and have proposed that radial glia cells act as neuronal precursor cells. The type I cells of our study share many morphological properties with the B cell (Seri et al., 2001), further suggesting that type I cells are early progenitors in the DG.

A surprising result in the present study was the extremely high IR of the type II cells, which ranged from $532 \mathrm{M} \Omega$ to $8.46 \mathrm{G} \Omega$. The IR of mature granule neurons, measured by whole-cell recordings, has been reported to be $388 \mathrm{M} \Omega$ in adult mouse (van Praag et al., 2002), 182-248 M $\Omega$ in adult rat (Wang et al., 2000), 261.8 $\mathrm{M} \Omega$ in young rat (Mott et al., 1997), and $202 \mathrm{M} \Omega$ (this study). Therefore the IR of type II cells measured here does not fall into any documented range. Such a high value of IR in DG has not been reported in any study except that by Liu et al. (2000), in which the relationship between morphological maturity and electroresponsive properties of DG granule cells was analyzed. They reported in developing rat DG that the IR of morphologically immature granule cells is extremely high (2-3 G $\Omega$ ), whereas that of mature neurons is significantly lower $(100-350 \mathrm{M} \Omega$ ). Noctor et al. (2001) reported that in developing neocortex, the IR of migrating neurons outside of the DG was as high as $1.03 \mathrm{G} \Omega$.

Our study also demonstrated that type II cells expressed voltage-gated inward currents and were costained with PSANCAM, a specific marker for immature neurons in the hippocampus (Seki and Arai, 1993; Kuhn et al., 1996; Nacher et al., $2001 \mathrm{~b}$ ). Taking our results together with those of several other studies (Palmer et al., 2000; Blümcke et al., 2001; Gu et al., 2002) in which expression of nestin in neuronal precursor cells with a morphology similar to the type II cells in this study, we propose that type II cells are late progenitors at an early stage of neuronal differentiation in the adult DG. The expression of the neuron-like fast inward current in type II cells is strong evidence supporting the possibility that type II cells serve as neuronal progenitor cells.

In conclusion, the use of the nestin promoter-GFP transgenic mouse has permitted us to characterize two distinct subpopulations of nestin-positive cells in the DG of mature animals, which might have important implications in developing our understanding of the process of neurogenesis in the adult brain.

\section{References}

Altman J, Das GD (1965) Autoradiographic and histological evidence of postnatal hippocampal neurogenesis in rats. J Comp Neurol 124:319-335.

Altman J, Das GD (1967) Postnatal neurogenesis in the guinea-pig. Nature 214:1098-1101.

Alvarez-Buylla A, Buskirk DR, Nottebohm F (1987) Monoclonal antibody reveals radial glia in adult avian brain. J Comp Neurol 264:159-170.

Auerbach JM, Eiden MV, McKay RD (2000) Transplanted CNS stem cells form functional synapses in vivo. Eur J Neurosci 12:1696-1704.

Blümcke I, Schewe JC, Normann S, Brüstle O, Schramm J, Elger CE, Wiestler OD (2001) Increase of nestin-immunoreactive neural precursor cells in the dentate gyrus of pediatric patients with early-onset temporal lobe epilepsy. Hippocampus 11:311-321.

Bordey A, Sontheimer H (2000) Ion channel expression by astrocytes in situ: comparison of different CNS regions. Glia 30:27-38.

Cameron HA, Woolley CS, McEwen BS, Gould E (1993) Differentiation of newly born neurons and glia in the dentate gyrus of the adult rat. Neuroscience 56:337-344.

Eckenhoff MF, Rakic P (1984) Radial organization of the hippocampal dentate gyrus: a Golgi, ultrastructural, and immunocytochemical analysis in the developing rhesus monkey. J Comp Neurol 223:1-21.

Eriksson PS, Perfilieva E, Björk-Eriksson T, Alborn AM, Nordborg C, Peter- son DA, Gage FH (1998) Neurogenesis in the adult human hippocampus. Nat Med 4:1313-1317.

Frederiksen K, McKay RD (1988) Proliferation and differentiation of rat neuroepithelial precursor cells in vivo. J Neurosci 8:1144-1151.

Fukuda S, Kato F, Yamaguchi M, Miyamoto Y, Hisatsune T (2002) Passive membrane properties of neural stem cells from the adult nestin-GFP mouse dentate gyrus. Soc Neurosci Abstr 28:127.5.

Gould E, Tanapat P, McEwen BS, Flügge G, Fuchs E (1998) Proliferation of granule cell precursors in the dentate gyrus of adult monkeys is diminished by stress. Proc Natl Acad Sci USA 95:3168-3171.

Gu H, Wang S, Messam CA, Yao Z (2002) Distribution of nestin immunoreactivity in the normal adult human forebrain. Brain Res 943:174-180.

Hockfield S, McKay RD (1985) Identification of major cell classes in the developing mammalian nervous system. J Neurosci 5:3310-3328.

Kaplan MS, Bell DH (1984) Mitotic neuroblasts in the 9-d-old and 11month-old rodent hippocampus. J Neurosci 4:1429-1441.

Kaplan MS, Hinds JW (1977) Neurogenesis in the adult rat: electron microscopic analysis of light radioautographs. Science 197:1092-1094.

Kato F, Shigetomi E (2001) Distinct modulation of evoked and spontaneous EPSCs by purinoceptors in the nucleus tractus solitarii of the rat. J Physiol (Lond) 530:469-486.

Kempermann G, Gast D, Kronenberg G, Yamaguchi M, Gage FH (2003) Early determination and long-term persistence of adult-generated new neurons in the hippocampus of mice. Development 130:391-399.

Koketsu D, Mikami A, Miyamoto Y, Hisatsune T (2003) Nonrenewal of neurons in the cerebral neocortex of adult Macaque monkeys. J Neurosci 23:937-942.

Kosaka T, Hama K (1986) Three-dimensional structure of astrocytes in the rat dentate gyrus. J Comp Neurol 249:242-260.

Kressin K, Kuprijanova E, Jabs R, Seifert G, Steinhäuser C (1995) Developmental regulation of $\mathrm{Na}^{+}$and $\mathrm{K}^{+}$conductances in glial cells of mouse hippocampal brain slices. Glia 15:173-187.

Kuhn HG, Dickinson-Anson H, Gage FH (1996) Neurogenesis in the dentate gyrus of the adult rat: age-related decrease of neuronal progenitor proliferation. J Neurosci 16:2027-2033.

Lendahl U, Zimmerman LB, McKay RD (1990) CNS stem cells express a new class of intermediate filament protein. Cell 60:585-595.

Liu X, Tilwalli S, Ye G, Lio PA, Pasternak JF, Trommer BL (2000) Morphologic and electrophysiologic maturation in developing dentate gyrus granule cells. Brain Res 856:202-212.

LoTurco JJ, Blanton MG, Kriegstein AR (1991) Initial expression and endogenous activation of NMDA channels in early neocortical development. J Neurosci 11:792-799.

Matthias K, Kirchhoff F, Seifert G, Hüttmann K, Matyash M, Kettenmann H, Steinhäuser C (2003) Segregated expression of AMPA-type glutamate receptors and glutamate transporters defines distinct astrocyte populations in the mouse hippocampus. J Neurosci 23:1750-1758.

McKhann II GM, D’Ambrosio R, Janigro D (1997) Heterogeneity of astrocyte resting membrane potentials and intercellular coupling revealed by whole-cell and gramicidin perforated-patch recordings from cultured neocortical and hippocampal slice astrocytes. J Neurosci 17:6850-6863.

Miyakawa N, Uchino S, Yamashita T, Okada H, Nakamura T, Kaminogawa S, Miyamoto Y, Hisatsune T (2002) A glycine receptor antagonist, strychnine, blocked NMDA receptor activation in the neonatal mouse neocortex. NeuroReport 13:1667-1673.

Miyata T, Kawaguchi A, Okano H, Ogawa M (2001) Asymmetric inheritance of radial glial fibers by cortical neurons. Neuron 31:727-741.

Mott DD, Turner DA, Okazaki MM, Lewis DV (1997) Interneurons of the dentate-hilus border of the rat dentate gyrus: morphological and electrophysiological heterogeneity. J Neurosci 17:3990-4005.

Nacher J, Rosell DR, Alonso-Llosa G, McEwen BS (2001a) NMDA receptor antagonist treatment induces a long-lasting increase in the number of proliferating cells, PSA-NCAM-immunoreactive granule neurons and radial glia in the adult rat dentate gyrus. Eur J Neurosci 13:512-520.

Nacher J, Crespo C, McEwen BS (2001b) Doublecortin expression in the adult rat telencephalon. Eur J Neurosci 14:629-644.

Noctor SC, Flint AC, Weissman TA, Dammerman RS, Kriegstein AR (2001) Neurons derived from radial glial cells establish radial units in neocortex. Nature 409:714-720.

Noctor SC, Flint AC, Weissman TA, Wong WS, Clinton BK, Kriegstein AR (2002) Dividing precursor cells of the embryonic cortical ventricular 
zone have morphological and molecular characteristics of radial glia. J Neurosci 22:3161-3173.

Palmer TD, Willhoite AR, Gage FH (2000) Vascular niche for adult hippocampal neurogenesis. J Comp Neurol 425:479-494.

Rickmann M, Amaral DG, Cowan WM (1987) Organization of radial glial cells during the development of the rat dentate gyrus. J Comp Neurol 264:449-479.

Schmidt-Kastner R, Szymas J (1990) Immunohistochemistry of glial fibrillary acidic protein, vimentin and S-100 protein for study of astrocytes in hippocampus of rat. J Chem Neuroanat 3:179-192.

Seki T (2002) Expression patterns of immature neuronal markers PSANCAM, CRMP-4 and NeuroD in the hippocampus of young adult and aged rodents. J Neurosci Res 70:327-334.

Seki T, Arai Y (1993) Highly polysialylated neural cell adhesion molecule (NCAM-H) is expressed by newly generated granule cells in the dentate gyrus of the adult rat. J Neurosci 13:2351-2358.

Seki T, Arai Y (1999) Temporal and spatial relationships between PSANCAM-expressing, newly generated granule cells and radial glia-like cells in the adult dentate gyrus. J Comp Neurol 410:503-513.
Seri B, Garcia-Verdugo JM, McEwen BS, Alvarez-Buylla A (2001) Astrocytes give rise to new neurons in the adult mammalian hippocampus. J Neurosci 21:7153-7160.

Tamamaki N, Nakamura K, Okamoto K, Kaneko T (2001) Radial glia is a progenitor of neocortical neurons in the developing cerebral cortex. Neurosci Res 41:51-60.

van Praag H, Schinder AF, Christie BR, Toni N, Palmer TD, Gage FH (2002) Functional neurogenesis in the adult hippocampus. Nature 415:1030-1034.

Wang S, Scott BW, Wojtowicz JM (2000) Heterogeneous properties of dentate granule neurons in the adult rat. J Neurobiol 42:248-257.

Yamaguchi M, Saito H, Suzuki M, Mori K (2000) Visualization of neurogenesis in the central nervous system using nestin promoter-GFP transgenic mice. NeuroReport 11:1991-1996.

Zimmerman L, Parr B, Lendahl U, Cunningham M, McKay R, Gavin B, Mann J, Vassileva G, McMahon A (1994) Independent regulatory elements in the nestin gene direct transgene expression to neural stem cells or muscle precursors. Neuron 12:11-24. 